AC 2010-2343: MARRYING MANUFACTURING PROGRAMS WITH BIOLOGICAL AND BIOMEDICAL ENGINEERING FIELDS

Arif Sirinterlikci, Robert Morris University

John Mativo, The University of Georgia 


\section{Marrying Manufacturing Programs with Bioengineering and Biomedical Engineering Fields and More}

\section{Introduction}

This paper focuses on program and curriculum development in order to sustain and enhance manufacturing engineering programs. The idea of emphasizing product design and development or integration of micro- or nano-manufacturing into manufacturing curriculum is attractive and important for the survival of the discipline. On the contrary, marrying manufacturing programs with biological and biomedical engineering fields may present a strong alternative. This study will sketch out a manufacturing engineering curriculum with a minor in bio- or biomedical engineering as well as a double major opportunity and BS/MS combined integrated programs. Possible course offerings will be included through course descriptions within materials, design, and manufacturing thrust areas and can be found in the appendix. A discussion on ABET implications of this program development effort and targeted application fields such agricultural and food processing, energy manufacturing, biological and biomedical, and pharmaceutical will complement the argument made by the authors. The paper will conclude with an extra-curricular approach in generating excitement to attract secondary and college students into the bio-related manufacturing programs through competitions, science fairs, and conferences. Establishment of the new SME Bioengineering Tech Group and its role in the current and future development efforts will be included in the concluding sections of this study.

\section{Incorporating Bioengineering or Biomedical Engineering into Manufacturing Engineering} Programs

There are currently only a few ABET accredited B.S. Manufacturing Engineering programs in the U.S. Figure. 1 bellow illustrates a check list for one of them. The program has 126 credits and can be broken down to six components as the university core, business courses, mathematics and science requirements, basic engineering courses, major courses, and electives:

- University Core (41 credits total):

○ CHEM1210 Chemistry I (3)

○ CHEM1215 Chemistry I Lab (1)

○ One from:

- COSK1220 Reading and Writing Strategies (3)

- COSK2221 Intercultural Communications (3)

- COSK1221 Argument and Research (3)

- COSK2220 Public Speaking and Persuasion

- COSK 2230 Business Professional Communication (3)

- ECON1010 Survey of Economics (3)

- HUMA1010 Humanities: Art and Music

- INFS1010 Introduction to Decision Support Systems

- MATH2070 Calculus with Analytical Geometry I (4) 


\section{Manufacturing Engineering Model Plan ( 126 Credits )}

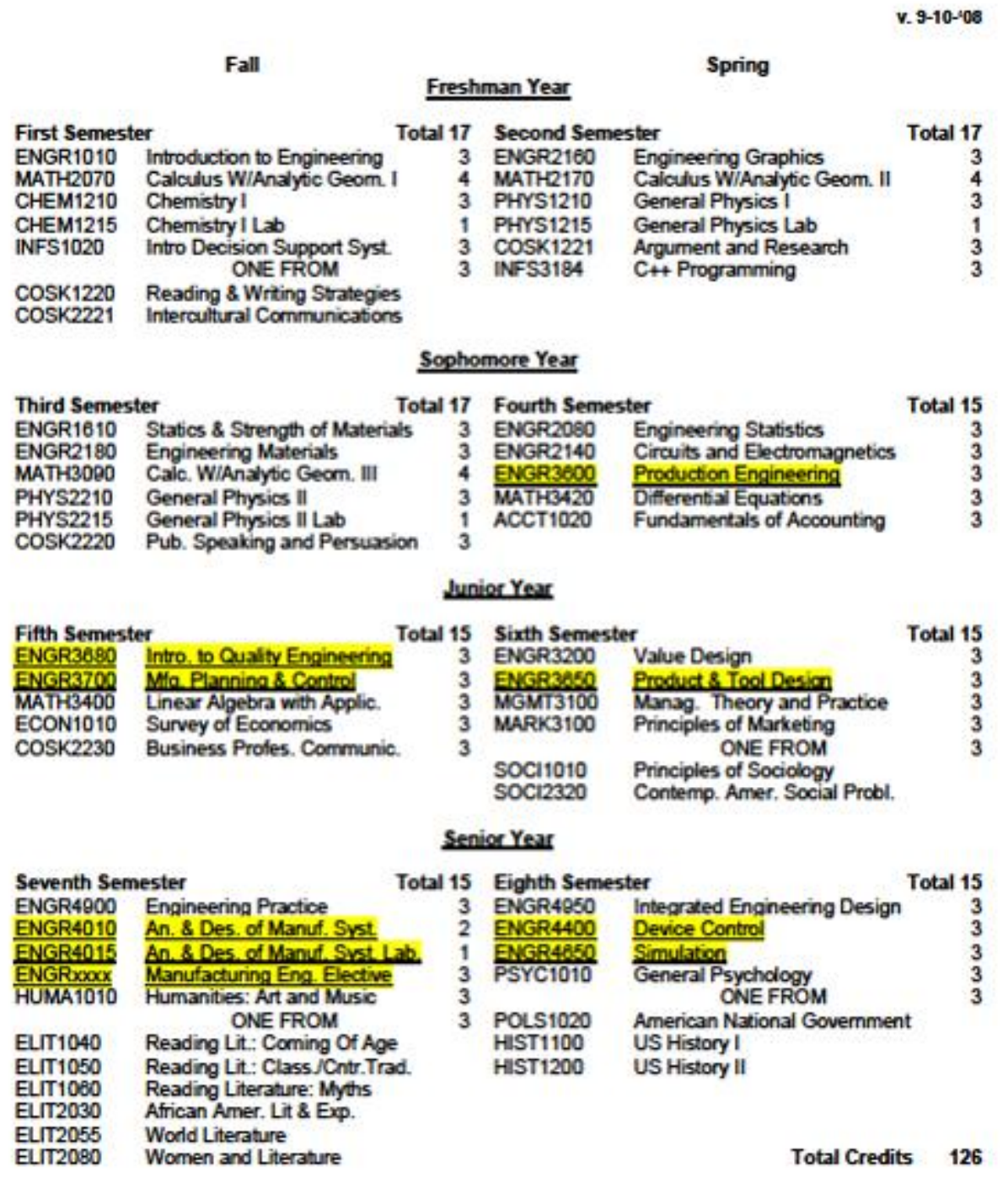

Figure 1. Check-sheet for the BS in Manufacturing Engineering - ABET accredited

○ PYSC1010 General Psychology (3)

- SOCI1010 Contemporary American Social Problems (3)

- One from:

- ELIT1040 Reading Literature:Coming of Age (3)

- ELIT1050 Reading Literature:Classics/Central Traditions (3)

- ELIT1060 Reading Literature: Myths (3)

- ELIT2030 African American Literature and Experience (3)

- ELIT2055 World Literature (3) 


$\begin{array}{rll} & \text { ELIT2080 } & \text { Women and Literature (3) } \\ \text { One from: } & \text { ELIT2040 } & \text { Literature and Medicine (3) } \\ & \text { HIST1100 } & \text { United States History I (3) } \\ \text { : } & \text { HIST1200 } & \text { United States History II (3) } \\ \text { HIST1500 } & \text { Western Civilization To 1715 (3) } \\ \text { : } & \text { POLS1020 } & \text { Western Civilization From 1715 (3) } \\ \text { HIST1700 } & \text { World Civilization I (3) } \\ \text { - HIST1800 } & \text { World Civilization Since 1500 (3) }\end{array}$

- Business Courses ( 9 credits total):

○ ACCT1020 Fundamentals of Accounting (3)

- MARK3100 Principles of Marketing (3)

○ MGMT3100 Management Theory and Practice (3)

- Mathematics and Science Requirements (25 credits total):

○ ENGR 2080 Engineering Statistics (3)

- MATH 2170 Calculus with Analytical Geometry II (4)

- MATH3090 Calculus with Analytical Geometry II (4)

- MATH3400 Linear Algebra with Applications (3)

- MATH3420 Differential Equations (3)

- PHYS1210 General Physics I (3)

○ PHYS1215 General Physics I Lab (1)

- Basic Engineering Courses (12 credits total):

o One from:

- ENGR1610 Statics and Strength Of Materials

- ENGR3110 Thermodynamics and Energetics

○ One from:

- ENGR2140 Circuits and Electromagnetics

- ENGR3110 Thermodynamics and Energetics

O One from:

- ENGR2160 Engineering Graphics

- ENGR3110 Thermodynamics and Energetics

- One from:

- ENGR2180 Engineering Materials

- ENGR3110 Thermodynamics and Energetics

- Major Courses ( 33 credits total):

- ENGR1010 Introduction To Engineering (3)

- ENGR3200 Value Design (3)

○ ENGR3600 Production Engineering (3)

- ENGR3650 Product and Tool Design (3)

- ENGR3680 Introduction To Quality Engineering (3)

○ ENGR3700 Manufacturing Planning and Control (3) 
- ENGR4400 Device Control (3)

- ENGR4650 Simulation (3)

- ENGR4900 Engineering Practice (3)

○ ENGR4950 Integrated Engineering Design (3)

○ INFS3184 C++ Programming (3)

- Electives (6 credits total):

o One from:

- ENGR3250 Automated identification Systems (3)

- ENGR4010 Analysis and Design of Manufacturing Systems (3)

- ENGR4030 Project Engineering (3)

- ENGR4200 Safety and Methods Engineering (3)

- ENGR4700 Robotics and Automation (3)

- ENGR4801 Rapid Prototyping and Reverse Engineering (3)

○ One from:

- ENGR3080 Design Of Industrial Experiments

- ENGR3250 Automated identification Systems (3)

- ENGR4030 Project Engineering (3)

- ENGR4200 Safety and Methods Engineering (3)

- ENGR4700 Robotics and Automation (3)

- ENGR4801 Rapid Prototyping and Reverse Engineering (3)

In Figure 1, the nine highlighted engineering courses are manufacturing specific courses. There is a major contradiction between the break-down of the program above and the check-sheet in Figure 1. This is due to a choice by the Engineering Department by designating the ENGR 4010 Analysis and Design of Manufacturing Systems course as most of the manufacturing students' first elective. Only some are allowed to take two from a list of courses in the electives section of the curriculum (mentioned right above).

The following section will offer multiple alternatives in engaging manufacturing programs with bioengineering or biomedical engineering fields:

1. First alternative solution to marrying manufacturing with biomedical or bioengineering is allowing and encouraging students to have double majors. This is not an actual combination of programs but allows manufacturing students to gain valuable background in the fields mentioned and adds to their versatilities. The Engineering Department housing the BS in Manufacturing Engineering program also offers multiple tracks in its BS in Engineering degree including the one in biomedical engineering. The check-sheet for that program is given in Figure 2: (i) Only four courses are highlighted in that checksheet as biomedical specific. These are ENGR 2510 Biomedical Engineering Principles, ENGR 3510 Biomechanics, ENGR 4520 Design and Manufacturing of Biomedical Devices and Systems, and a mechanical or manufacturing elective or ENGR 4510 Introduction to Biomaterials (not listed in Figure 2). Their course descriptions can be found in the appendix section of this paper. (ii) To able to gain the second major, 

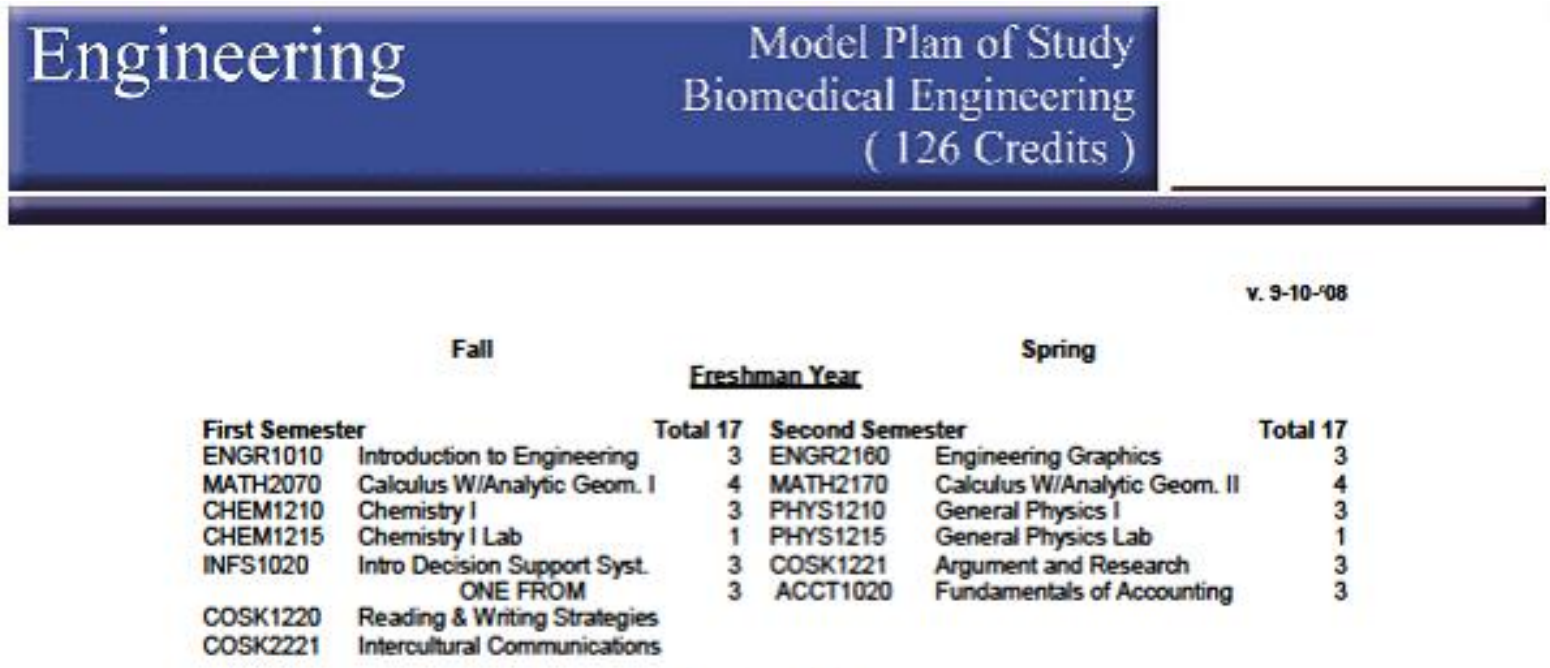

Sophomore Year

\begin{tabular}{ll} 
Third Semester & \multicolumn{1}{c}{ Total } \\
ENGR1610 & Statics \& Strength of Materials \\
MATH 3000 & Calc. WIAnalytic Geom. III \\
PHYS2210 & General Physics II \\
PHYS2215 & General Physics II Lab \\
BIOL1210 & Anat. \&. Physiology. \\
BIOL1215 & Anat. 8. Physiology ILab.
\end{tabular}
$\begin{array}{rll}\text { Total 15 } & \text { Fourth Semester } \\ 3 & \text { ENGR2510 } \\ 4 & \text { ENGR2140 } \\ 3 & \text { ENGR3110 } \\ 1 & \text { MATH3420 } \\ 3 & \\ 1 & \text { CHEMP210 } \\ & \text { CHEM2215 } \\ & & \text { CHE }\end{array}$ $\frac{\text { BIOL. } 1220}{\text { BiC. } 1225}$ Junior Year

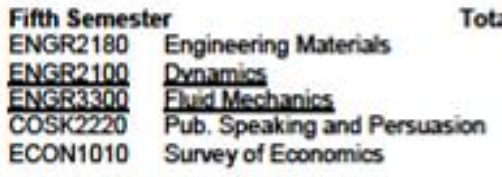

\begin{tabular}{|c|c|c|}
\hline Total 15 & Sixth Semester & \\
\hline & ENGR2080 & Engineering Statistics \\
\hline 3 & ENGR3200 & Vaive Design \\
\hline & ENGR3510 & Biomechanies \\
\hline 3 & MGMT3100 & Manag. Theory and Practice \\
\hline & $\begin{array}{l}\text { SOC11010 } \\
\text { SOCI2320 }\end{array}$ & $\begin{array}{l}\text { Principles of Sociology } \\
\text { Contemp. Amer. Social Probl. }\end{array}$ \\
\hline
\end{tabular}

Senior Year

\begin{tabular}{|c|c|c|c|}
\hline rotal 15 & Eighth Semest & & Total 1 \\
\hline & ENGR4850 & Integrated Engineering Design & \\
\hline 3 & ENGR4520 & Des. \& Mfg. BME Dev. Sys & \\
\hline 3 & MARK 3100 & Principles of Marketing & \\
\hline 3 & PSYC1010 & General Psychology & \\
\hline & & & \\
\hline & POLS1020 & American National Govemment & \\
\hline & $\begin{array}{l}\text { HIST1100 } \\
\text { HIST1200 }\end{array}$ & $\begin{array}{l}\text { US History I } \\
\text { US History II }\end{array}$ & \\
\hline
\end{tabular}

Figure 2. Check sheet for the BS in Engineering/Biomedical Track - ABET accredited

manufacturing students also need to take BIOL1210 Anatomy and Physiology I and BIOL1215 Anatomy and Physiology I Lab, and either CHEM2210 Chemistry II and CHEM2215 Chemistry II Lab, or BIOL1220 Anatomy and Physiology II and BIOL1225 Anatomy and Physiology II Lab. (iii) The biomedical track also requires three mechanical courses in ENGR 2100 Dynamics, ENGR 3110 Thermodynamics and Energetics, and ENGR 3300 Fluid Mechanics as prerequisites to the biomedical courses. 
Based on their curriculum manufacturing students will have one manufacturing elective and possibly the ENGR 3110 Thermodynamics and Energetics course leaving them with the following course requirements to graduate with the second major:

Table 1. Course list for the double major alternative (26 credits minimum)

\begin{tabular}{|l|l|l|}
\hline Course Number & Course Name & Credits \\
\hline BIOL1210 & Anatomy and Physiology I & 3 \\
\hline BIOL1215 & Anatomy and Physiology I Lab & 3 \\
\hline One set from & CHEM2210 Chemistry II & 3 \\
& CHEM2215 Chemistry II Lab & 1 \\
& or & \\
& BIOL1220 Anatomy and Physiology II & \\
& BIOL1225 Anatomy and Physiology II Lab & 3 \\
\hline ENGR2100 & Dynamics & 3 \\
\hline ENGR3300 & Fluid Mechanics & 3 \\
\hline ENGR2510 & Biomedical Engineering Principles & 3 \\
\hline ENGR3510 & Biomechanics & 4 \\
\hline ENGR4520 & Design and Manufacturing of Biomedical Devices and & \\
\hline & Systems & \\
\hline
\end{tabular}

Total number of courses for this alternative is 9 and the total credit amount is 26 credits as shown in Table 1. Considering that the students take 15 to 17 credits each term, this option will add 1 and $1 / 2$ terms to their curriculum. The students can also take the 3 credit ENGR 4510 Introduction to Biomaterials course keeping the addition still at one year.

2. Second alternative solution is to use the minor system in the university. The university's minors are 12 - 20 credits in length. Engineering students at this university have been considering and earning Business and Mathematics Minors. Especially Mathematics Minor has been popular with manufacturing students since they only need 6 additional credits or two 3 credit hour courses for this minor (four of their MATH courses count for the minor). The authors propose two minors as explained in Tables 2 and 3:

Table 2. Course list for the minor alternative - option 1 (19 credits minimum)

\begin{tabular}{|l|l|l|}
\hline Course Number & Course Name & Credits \\
\hline BIOL1210 & Anatomy and Physiology I & 3 \\
\hline BIOL1215 & Anatomy and Physiology I Lab & 1 \\
\hline One from & $\begin{array}{l}\text { ENGR 4520 Design and Manufacturing of Biomedical } \\
\text { Devices and Systems } \\
\text { or } \\
\text { ENGR4510 Introduction to Biomaterials }\end{array}$ & $\begin{array}{l}4 \\
\text { or } \\
\end{array}$ \\
\hline ENGR2100 & Dynamics & 3 \\
\hline ENGR3300 & Fluid Mechanics & 3 \\
\hline ENGR2510 & Biomedical Engineering Principles & 3 \\
\hline ENGR3510 & Biomechanics & 3 \\
\hline
\end{tabular}


Table 3. Course list for the minor alternative - option 2 ( 23 credits minimum)

\begin{tabular}{|l|l|l|}
\hline Course Number & Course Name & Credits \\
\hline BIOL1210 & Anatomy and Physiology I & 3 \\
\hline BIOL1215 & Anatomy and Physiology I Lab & 1 \\
\hline One set from & CHEM2210 Chemistry II & 3 \\
& CHEM2215 Chemistry II Lab & 1 \\
& or & or \\
& BIOL1220 Anatomy and Physiology II & 3 \\
& BIOL1225 Anatomy and Physiology II Lab & \\
& or & \\
\hline ENGR2100 & Dynamics Introduction to Biomaterials & 3 \\
\hline ENGR3300 & Fluid Mechanics & 3 \\
\hline ENGR2510 & Biomedical Engineering Principles & 3 \\
\hline ENGR3510 & Biomechanics & 3 \\
\hline ENGR4520 & Design and Manufacturing of Biomedical Devices and & 4 \\
\hline & Systems & \\
\hline
\end{tabular}

The first minor option has reasonable length compared to the other minors at the university. On the contrary, the second minor option is comparable to the credit requirements for the double major option. However, having a double major is more advantageous compared to the second minor option. A third minor alternative may be developed to include a manufacturing course like ENGR 4801 Reverse Engineering and Rapid Prototyping with medical and forensics content to reduce the number of credits to 20.

3. The third alternative is to design an integrated 5 year BS/MS program. This can be done in various combinations including an in-house option or with a partner school. In such a program students start taking graduate courses in their $4^{\text {th }}$ year as illustrated in Figure 3. If the partnership requires students to take courses from another institution in their $4^{\text {th }}$ year, multiple means can be employed including student traveling to the nearby institution or taking distance courses. Figure 3 is the check-sheet for an integrated BS (Manufacturing Engineering)/MS (Engineering Management) program saving students 6 credits from the 30 credit graduate program. The university also waives the Graduate Record Examination (GRE) requirement for its students continuing into the MS program. Alternative areas for the MS portion can be Bioengineering, Agricultural and Food Processing, and Pharmaceutical Engineering or Manufacturing. Universities such as Rutgers ${ }^{1}$ or Stevens Institute of Technology ${ }^{2}$ have Pharmaceutical Engineering or Manufacturing MS programs due to strong presence of pharmaceutical industry in New Jersey. On the contrary, University of Pittsburgh ${ }^{3}$ has specialty in Bioengineering due to presence of a successful University of Pittsburgh Medical Center (UPMC) and other medical institutions in Pittsburgh. If you are in Ohio or nearby, you can also look into collaborating with Ohio State's College of Food, Agricultural, and Environmental Sciences ${ }^{4}$. 


\section{Manufacturing Eng. Intregrated Program B.S. \\ $(126+24$ Credits $)$}

Fall

Ereshman Year

Spring

First Semester

ENGR1010 Introduction to Engineering

MATH2070 Calculus W/Analytic Geom. I

CHEM1210 Chemistry !

CHEM1215 Chemistry I Lab

INFS1020 Intro Decision Support Syst. ONE FROM

COSK1220 Reading \&. Writing Strategies

cosk2221 intercultural Communications

Total 17 Second Semester

3 ENGR2160 Engineering Graphics

4 MATH2170 Calculus W/Analytic Geom. II

3 PHYS1210 General Physics I

1 PHYS1215

3 COSK 1221

3 INFS3184

General Physics Lab

Argument and Research

$\mathrm{C}++$ Programming

Total 17

Sephomore Year

Third Semester

ENGR1610 Statics \& Strength of Materia's

ENGR2180 Engineering Materials

MATH3090 Calc. WIAnalytic Geom. III

PHYS2210 General Physics I

PHYS2215 General Physics ll Lab

$\cos 12220$ Pub. Speaking and Persuasion

Total 17 Fourth Semester

$\begin{array}{rllr}17 & \text { Fourth Semester } & \text { Total } 15 \\ 3 & \text { ENGR2080 } & \text { Engineering Statistics } & 3 \\ 3 & \text { ENGR2140 } & \text { Circuits and Electromagnetics } \\ 4 & \text { ENGR2900 } & \text { Production Engineering } & 3 \\ 3 & \text { MATH3420 } & \text { Differential Equations } & 3 \\ 1 & \text { ACCT1020 } & \text { Fundamentals of Accounting } & 3 \\ 3 & & & \end{array}$

Junior Year ENGR3680 ENGR3700 MATH3400

ECON1010

Intre to Quality Enaineering Alto. Planning \& Control Linear Algebra with Applic.

Survey of Economics

$\operatorname{COSK} 2230$ Business Protes. Communic.

Total 15 Sixth Semester

3 ENGR3200

3 MARK3100

Production Tool \& Desion

Principles of Marketing ONE FROM

Socl1010 Principles of Sociology

SOC12320 Contemp. Amer. Social Probl.

Total 15

Senior Year

Seventh Semester Undergraduate Total 15 Eighth Semester

ENGR4010 An. \& Des of Manut. Syst.

ENGR4015

ENGRXOXX

HUMA1010

An. 8 Des. of Manut. Syst. Lab

Manufacturing Enq. Elective

Humanties: Art and Music ONE FROM

ELIT1040 Reading Lit: Coming Of Age

ELIT1050 Reading LI:Class/Cntr.Trad

ELIT1060 Reading Literature: Myths

ELIT2030 African Amer. Lì \& Exp.

ELIT2055 World Literature

ELIT2080 Women and Literature

3 ENGR4950 Integrated Engineering Design Total 15

1 ENGR4850

PSYC1010

3 POLS1020

US History 1

Device Contro:

Simulation

General Psychology ONE FROM

3

15
3
3
3
3
3

ENGR50

S History I

Total Undergraduate Credits

126

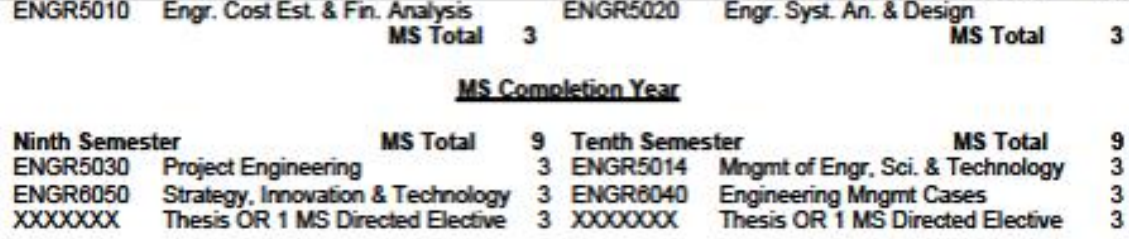

Total Graduate Credits 24

Figure 3. Check-sheet for the BS in Manufacturing/MS in Engineering Management

(Levels 5000 and above are reserved for graduate courses) 


\section{Development of a Bioengineering Specialty under Society of Manufacturing Engineers Umbrella}

This section of the paper presents the development efforts of a new specialty in bioengineering within the Society of Manufacturing Engineers (SME) Manufacturing Education and Research (MER) Community structure. Critical importance of this initiative lies in finding extracurricular ways to engage manufacturing community and its future including college and high school students with the growing applications fields in bioengineering and biomedical engineering. Additional activities in course and program development are also planned. While both authors are engaged in this group, the lead author of this paper is the current chair of this effort.

Biotechnology has existed since ancient times, however some of its most dramatic advances have been realized recently. Not too long ago, it was described as manipulation of biological organisms or materials to make products and systems benefiting humans. However, its span was limited to food production, waste disposal, or medicine ${ }^{5}$. Subsets of biotechnology have been rapidly growing. One such subset is biomedical technology. Its products save, prolong, and improve human life through physiological monitoring and processing, pharmaceuticals, and prosthetics. Its specialties such as bionics ${ }^{6}$ and bioprinting ${ }^{7}$ are gaining momentum thanks to innovative neuro-prosthetics, bionic eye or ear development, and tissue and organ engineering respectively. On the other hand, another subset, biomaterials is searching for organic substitutes for engineering materials. Biofuel ${ }^{8}$ development and bacteria-based energy generation ${ }^{9}$ are occupying minds of the many. While DNA computing ${ }^{10}$ and bioinformatics ${ }^{11}$ are redefining the informatics field, biometrics ${ }^{12}$ is growing deeper in our daily lives. Most importantly we are starting experience a scientific revolution in our world through bionanotechnology ${ }^{13}$.

For the U.S. to keep its competitiveness in the cutting edge technology arena, its manufacturing sector needs to re-invent itself and get involved in these bio-related fields. This is also crucial for the survival of the manufacturing sector. SME has a very critical role in safeguarding the U.S. manufacturing sector, and assuring education and training of the current and prospective manufacturing personnel. Thus, the authors believe that there is a necessity for SME to be involved in development of such technical specialty, Bioengineering. In January 2007, Lee Loeb, a former membership consultant from Philadelphia Pennsylvania and Arif Sirinterlikci, the Faculty Advisor of SME Student Chapter at Robert Morris University near Pittsburgh Pennsylvania teamed up to propose a Bioengineering specialty ${ }^{14}$. After various interactions with SME, SME decided to allow the formation of this group under its Manufacturing Education and Research (MER) Community as a technical group. Since then a few other SME members have joined the group.

\section{Proposed Agenda of the Bioengineering Tech Group}

The Bioengineering technical group was established with the main idea of supporting manufacturing professionals who are involved in the bio-related fields, educational and research programs in manufacturing engineering and similar departments through ${ }^{15}$ : 
- Promotion of biotechnologies and related design and manufacturing engineering activities including research through a periodical electronic (and/or hardcopy) publication.

- Promotion of research through small-scale research initiation grants. The group will seek sponsors for these awards. The goal here is to get the industry and researchers together.

- Organization of an annual bioengineering conference that relates to design and manufacturing engineering fields (early possible locations include sites in MD, NJ, PA, and $\mathrm{OH}$ and other bio-tech intense areas of the US).

- Capturing and maintaining interest of K-12 students by:

- Getting involved in current engineering competitions such as JETS' Teams.

- Development of outreach activities through educational camps, media development and dissemination, or organization of secondary school club competitions under SME.

- Getting involved in development of new and existing bio-materials, design and manufacturing courses, and bio-engineering specialties in manufacturing engineering programs.

- Generation of resources for SME scholarships for students pursuing bioengineering fields and are interested in design and manufacturing.

- Generation of joint training activities for companies, summer programs including institutes and accelerated graduate programs at universities.

\section{Developments up to Date}

After the official recognition by SME, Mark Stratton, A Community Relations Manager from SME became the liaison between the Tech Group and SME. A monthly teleconference schedule and a web page is established ${ }^{16}$. However, after a few teleconferences the attendance became an issue due to date and time of the meetings. The group members reached other groups through several listservs, the active core remained small even with various e-mail messages arriving from the interested. Other tech groups contacted included Medical Applications and Nanotechnology.

Additional opportunities were brought by the SME Liaison to keep the group active and to promote its members work. These included:

- Publishing articles about the group and its activities including its members works in the SME's Medical Yearbook and the Manufacturing Engineering Magazine

- Presenting at an International Society of Pharmaceutical Engineers (ISPE) event in Sommerset, New Jersey in June $2008{ }^{16}$.

○ Presentations at the ISPE event included (i) Surface Engineering for Medical Devices: Biocompatibility, Friction, Coating Issues, (ii) An Innovative Method for Tissue Scaffold Design, Manufacturing and Testing, (iii) Rapid Prototyping and Manufacturing in Medical (and Dental) Applications, and (iv) Kinesiology: the Study of Movement.

Since then, the group represented SME at INTERPHEX Canada, another ISPE event held in Montreal Quebec, and agreed to work with the Nanotechnology Tech Group within the SME's Nanomanufacturing Conference organization. Meanwhile Bioengineering Tech Group Webinar Series has started with a successful presentation on his cutting-edge research in Tissue 
Engineering by Drexel University's Jack Zhou. Professor Zhou is one of the few core members of the tech group. His presentation was on Micro-fluidic Array Printers for Fabricating Tissue Scaffolds and Subsequent Bone structure ${ }^{16}$. A second webinars was presented on March 26, 2009 at 12:30 PM E.S.T. It was delivered by Stephen Greenwald of (Queen Mary College) University of London. He focused on Mechanical Factors in Arterial Disease: Aging, Hypertension and Arterial Elasticity and how to deal with this health problem by the eye of an engineer not a medical doctor. A third webinar was delivered on December 15, 2009. It was on Atomic Force Microscopy (AFM): Enabling Characterization of Biological Structures and Forces at the NanoScale. The presenter was Andrea Slade, a research scientist from Veeco, a California company. AFM devices can be used in many applications including polymer science, tissue engineering and more. A fourth webinar is currently being planned for bio-energy subjects. Each webinar will last 1 and $1 / 2 \mathrm{hr}$ including a Q \& A session. After each webinar, the group will collect feedback on topics of interest for future webinars and gaging interest in the tech group activities by determining the number of attendees of the webinar and the associated demographic information.

\section{Proposed Plan of Action for Future Activities}

This section concludes with a discussion below on how to achieve the initial objectives and how to adjust the tech group agenda accordingly, that many can be impacted successfully:

- Promotion of biotechnologies and related design and manufacturing engineering activities including research through a periodical electronic (and/or hardcopy) publication. En route to achieving this, the group will initially employ its web page in posting articles and presentations belonging to its members. SME's Medical Year Book or Manufacturing Engineering Magazine will also be utilized by the group to promote its members research and engineering activities. A plan is being devised to develop a biannual electronic publication to be housed at the web page of the group.

- Promotion of research through small-scale research initiation grants. The group will seek sponsors for these awards. The goal here is to get the industry and researchers together. The group will modify this objective to - its members working together to obtain funding through local, state, and federal funding agencies. It will still bring the group members and their collaborators together in development of strong research proposals.

- Organization of an annual bioengineering conference that relates to design and manufacturing engineering fields (early possible locations include sites in MD, NJ, PA, and $\mathrm{OH}$ and other bio-tech intense areas of the US). The group is already in an agreement with the Nanotechnology Tech Group to help them on the 2010 Nanomanufacturing Conference. Other attempts are being made to connect with other groups including Society for Biological Engineering (SBE), Biomedical Engineering Society (BMES), and ISPE on receiving sessions at their events as well. The original target may be realized with joint help from other tech groups and communities of SME as well as the organizations mentioned above.

- Capturing and maintaining interest of K-12 students by:

○ Getting involved in current engineering competitions such as JETS. 
- Development of outreach activities through educational camps, media development and dissemination, or organization of secondary school club competitions under SME.

The group members are considering volunteering at the JETS Teams competition and contributing for local Science Fairs to get K-12 students' attention. A summer workshop will be developed based-on bio-inspired products and machines. This will be followed by development of a bio-based competition for grades 7-12.

- Getting involved in development of new and existing bio-materials, design and manufacturing courses and bio-engineering specialties in manufacturing engineering programs. Faculty members present at American Society for Engineering Education (ASEE) and SME Manufacturing Engineering Education Forums will be asked to sketch a minor or an option curriculum for Manufacturing Engineering programs. They will also be asked for their opinion on a separate degree that combines bio-related subjects with design and development, and manufacturing. Development of survey tools for both concepts is currently underway.

- Generation of resources for SME scholarships for students pursuing bioengineering fields and are interested in design and manufacturing. Within a few years of the initiation and active service, the group will seek sponsors for scholarships for secondary and college students who are interested in the bio-related fields.

- Generation of joint training activities for companies, summer programs including institutes and accelerated graduate programs at universities. Similar approach will be taken for this objective just like the undergraduate program development objective above. In addition, summer institutes and other certificate programs will be developed in corporation with biomedical degree offering entities and related societies and will be presented at the upcoming SME Manufacturing Education Forum.

\section{Conclusions}

This paper presents a two pronged approach in engaging manufacturing community in bioengineering and biomedical engineering. The first is to marry manufacturing and bio-related programs through minor, double major, and BS/MS combined degree options. All of the programs studied within the paper are ABET accredited and the solutions proposed do not influence the ABET balance of these programs. Some of the proposed ideas can also lead to further collaboration between the universities including collaborative research. The second prong is mainly about the extracurricular activities. Developments through the SME's Bioengineering Tech Group are also critical since they engage not only elementary, secondary, higher education students but also faculty and industry in many ways. Some of the group's activities can also be used in retooling current manufacturing engineers, technologists, and technicians. In terms of the future work, the authors will push the educational proposals as well as the SME Bioengineering Tech Group agenda forward with confidence of their outcomes. 


\section{References}

1. http://pharmeng.rutgers.edu/coursesCore.html

2. http://webcampus.stevens.edu/pharmaceutical-manufacturing.aspx

3. http://www.engr.pitt.edu/bioengineering/main/undergraduate/courses/index.html

4. http://cfaes.osu.edu

5. http://www.accessexcellence.org/RC/AB/BC/what_is_biotechnology.php

6. http://www.aleph.se/Trans/Individual/Body/bion_page.html

7. http://www.teal.u-bordeaux2.fr/3B09/

8. http://journeytoforever.org/biofuel.html

9. http://www.eurekalert.org/pub_releases/2006-05/asfm-rhh051706.php

10. http://www.princeton.edu/ lfl/FRS.html

11. Lesk, A. M., Introduction to Bioinformatics, Oxford University Press, 2002.

12. Ashbourn, J., Practical Biometrics: From Aspiration to Implementation, Springer Professional Computing, 2003.

13. http://www.ibnam.northwestern.edu/

14. SME Speaks: SME Forms Bioengineering Tech Group, Manufacturing Engineering, Vol. 140 No.4, April 2008.

15. Sirinterlikci, A., Proposal for Development of a Bioengineering Specialty under Society of Manufacturing Umbrella.

16. http://www.sme.org/bioengineering 
Appendix (Additional information of the prerequisites can be found within the body of the paper)

\section{ENGR2510 - Biomedical Engineering Principles}

This course provides an overview of the biomedical engineering discipline and major subdivisions, such as biomechanics, cellular engineering, tissue engineering, bioelectricity, and imaging. Also introduced are quantitative tools utilized throughout the biomedical engineering curriculum. The class will be involved in the formulation and execution of a design project.

Prerequisites: ENGR1610, BIOL1210 \& BIOL1215

3 Credits

\section{ENGR 3510 BiomechanicsENGR3510 - Biomechanics}

This course develops the application of the principles of continuum mechanics to biological tissues and systems. After briefly reviewing selected results from statics, strength of materials, dynamics, and fluid dynamics, the course details several constitutive equations of biological materials, properties of living tissue, and the mechanical basis and effects of pathology and trauma. The course emphasizes the mechanics of the muscle-skeletal and circulatory systems.

Prerequisites: ENGR2100, ENGR2510, and ENGR3300

3 Credits

\section{ENGR4510 - Introduction To Biomaterials}

This course provides an introduction to biomaterials, both synthetic and natural, that are implanted in the human body or employed in a medical device for the purposes of promoting improved human health. The course covers the synthesis, characterization, properties and applications of clinically significant biomaterials and discusses regulatory issues (legal, safety, reliability, biocompatibility, and ethics) concerning the use of biomaterials.

Prerequisites: ENGR1610, ENGR2180, and ENGR3510

3 Credits

\section{ENGR 4520 Design and Manufacturing of Biomedical Devices and Systems}

This course details the conception, modeling, analysis, design, manufacturing and assembly of Biomedical devices and systems. Students select, formulate, and solve a design problem and manufacture a prototype, as appropriate. Applications include, but are not limited to, diagnostic instrumentation, prostheses, and cardiovascular devices against the background of ethical considerations, Food and Drug Administration (FDA) regulations, and product-liability issues. Prerequisites: ENGR2180 and ENGR3510 4 Credits 